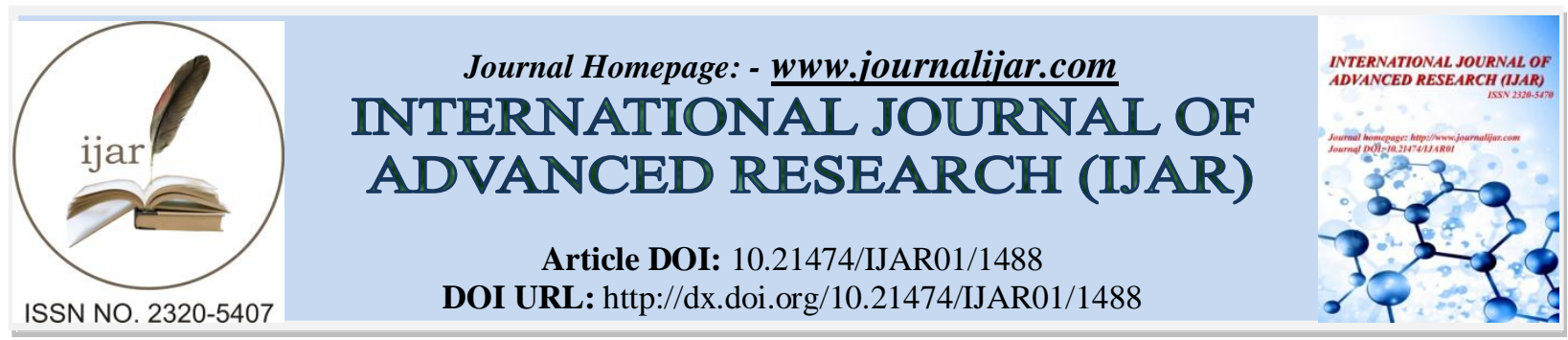

RESEARCH ARTICLE

\title{
SOME ETHNOMEDICINAL PLANT SPECIES OF NAGAUR DISTRICT AND THEIR ROLE IN CONTROL OF AIR POLLUTION.
}

\author{
Dileep Kumar $^{1 *}$, Brijendra Singh ${ }^{1}$ and R.A. Sharma ${ }^{2}$. \\ 1. Department of Botany, Stani Memorial PG College, Jaipur, 302020. \\ 2. Department of Botany, University of Rajasthan, Jaipur, 302004.
}

\section{Manuscript Info}

Manuscript History

Received: 12 July 2016

Final Accepted: 18 August 2016

Published: September 2016

Key words:-

APTI, Ethnomedicinal Plants.

\section{Abstract}

Nagaur district is situated between $26^{0} .25^{\prime \prime}$ and $27^{0} .40 "$ North latitude and $73^{0} .10^{\prime \prime}$ and $75^{0} .15^{\prime \prime}$ East longitude. Studies have been done on identification and exploration of the possibilities of ethnomedicinal plant species of Nagaur district (Kapoor and Kishore, 2013). The role of ethnomedicinal plant species in developing a healthy atmosphere is very desirable in the context of deteriorating environment resulting from increased urbanization, Industrialization and improper environmental management. These plant species are used for their potential to improve the design and development of healthy environment. It is necessary that plant species used must be tolerant to air pollution. In this study, dust removal capacities and Air pollution tolerance Index (APTI) of plants commonly used for green and shelterbelt establishment (Singh V., 2013). On the basis of APTI and some biological parameters of plant species study of different ethnomedicinal plant species like Acasia nilotica (L.) Willd. ex Delile, Albizia lebbeck (Linn.) Willd., Alianthus excelsa Roxb., Anthocephalus Cadamba (Roxb.) Miq., Azadirachta indica A. juss., Bougainvillea spectabilis Willd., Caesalpinia pulcherrima Linn., Dalbergia sissoo Roxb., Ficus religiosa Linn., Nyctanthes arbortristis Linn., Tamarindus indica Linn. and Thevetia neriifolia A.Juss. are done. These plant species have great potential to control the air pollution. The present study is aimed to create awareness about the ethnomedicinal value of the plant species and their role in the control of air pollution.

Copy Right, IJAR, 2016,. All rights reserved.

\section{Introduction}

Nagaur District is situated between $26^{\circ} .25^{\prime \prime}$ and $27^{\circ} .40^{\prime \prime}$ North latitude $\& 73^{\circ} .10^{\prime \prime}$ and $75^{\circ} .15^{\prime \prime}$ East longitude. It is situated amidst in seven districts namely Bikaner, Churu, Sikar, Jaipur, Ajmer, Pali and Jodhpur.

Nagaur is the fifth largest district in Rajasthan with vast terrain spreading over 17,718 sq. k.m. Its geographical spread is a good combine of plain, hills, sand mounds \& as such it is a part of the great Indian Thar desert.The medicinal plant species belong to different families such as Simarobuaceae, Oleaceae, Apocynaceae, Meliaceae, Fabaceae, Rubiaceae, Mimosaceae and Nyctaginaceae etc. 
Air pollution is the introduction of particulates, biological molecules or other harmful materials in tothe atmosphere, causing diseases, death to humans, damage to other living organisms such as natural environment. The atmosphere is a complex natural gaseous system that is essential to support life on earth. Stratospheric ozone depletion due to air pollution has been recognized as a threat to human health as well as to the ecosystem of the earth. An air pollutant is a substance in the air that can have adverse effect on humans and the ecosystem. The substances can be solid particles, liquid droplets or gases. The pollutants can be of natural or artificial. Pollutants are divided in to primary and secondary pollutants.

Primary pollutants are usually produced from a process, such as from volcanic eruptions, $\mathrm{CO}, \mathrm{SO} 2, \mathrm{NO} 2, \mathrm{~Pb}, \mathrm{Hg}$, CFCs and NH3. Secondary pollutants are not emitted directly, rather, they form in the air when primary pollutants react or interact such as ground level ozone.

Most of sources of air pollution are related to human's activities as a result of the modern life style. The main pollution sources include chemicals, industries, automobiles, coal-fired power plants, nuclear waste disposal activity, plastic factories etc. Agriculture air pollution comes from spraying of pesticides and herbicides. Harmful effects of pollution have both acute and chronic effects on human health. Health effects range anywhere from minor irritation of eyes and upper respiratory systems, heart disease, lung cancer and death. Ozone depletion is the result of air pollution.

The air pollution control is the process of reducing the release of pollutants from industries, wastes of chimneys, fossil-fuel (coal), thermal power plants etc. It is regulated by various environmental agencies that establish limits for the discharge of pollutants in to air (Singh V., 2013).

The control of emissions can be realized in the number of ways such as collection of pollutants, cooling, emission control in automobile engines (Sharma, P.D., 2014).

The planting of trees and shrubs for the control of pollution and improvement of environment is an effective way. The proper planning and planting scheme depends upon the type of pollution. Tolerants and dust absorbing trees and shrubs should be planted for bioremediation of environment.

\title{
Methodology
}

To Collect and document this valuable information, several field trips were made in the villages of Nagaur District. Repeated enquiries and group discussion on the use of some plant were made to ascertain the authenticity of information (Kapoor and Kishore, 2013).

Informations were also collected from the old literature, magazines, classical books and modern books etc. (Singh V., 2013).

\section{Observations}

Ethnomedicinal plant species of Nagaur District, used in control of air pollution are Acasia nilotica (L.) Willd. ex Delile, Albizia lebbeck (Linn.) Willd., Alianthus excelsa Roxb., Anthocephalus Cadamba (Roxb.) Miq., Azadirachta indica A. juss., Bougainvillea spectabilis Willd., Caesalpinia pulcherrima Linn., Dalbergia sissoo Roxb., Ficus religiosa Linn., Nyctanthes arbortristis Linn., Tamarindus indica Linn. and Thevetia neriifolia A.Juss.

\author{
Acasia nilotica (L.) Willd. ex Delile \\ Family:- Fabaceae \\ Local Name:- Babool, Kikar, Tikar \\ Features: \\ * This tree is a 5-20 metre height with a dense spheric crown. \\ * Stem and branches are usually dark to black coloured. \\ * The leaves are small and bipinnately. \\ * It can grows in the highly polluted area. \\ * It is planted along the road side, avenue tree, wind break and shelter belt. \\ * It is resistant to pollutants. \\ * It is used to control of pollution from automobiles.
}




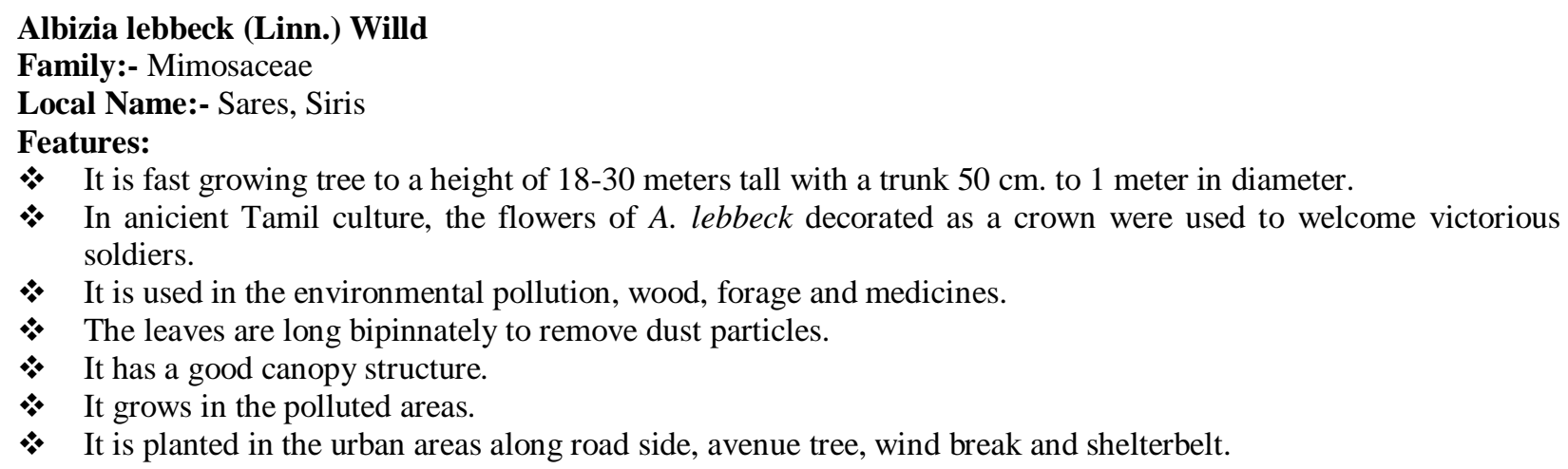

Alianthus excelsa Roxb

Family:- Simaroubaceae

Local Name:- Aradu, Aadu

Features:-

* It can grows in semi moist, semi arid region and highly polluted area.

* It is used as pollution indicator.

* It is planted along the road side, wind breaks and shelter belt.

* It has a good canopy structure.

* It can grow on a variety of soils but thrives best on porous sandy loams.

* The leaves are large in size and resistant to gaseous pollutants.

* The leaves are rich in crude protein and phosphorus.

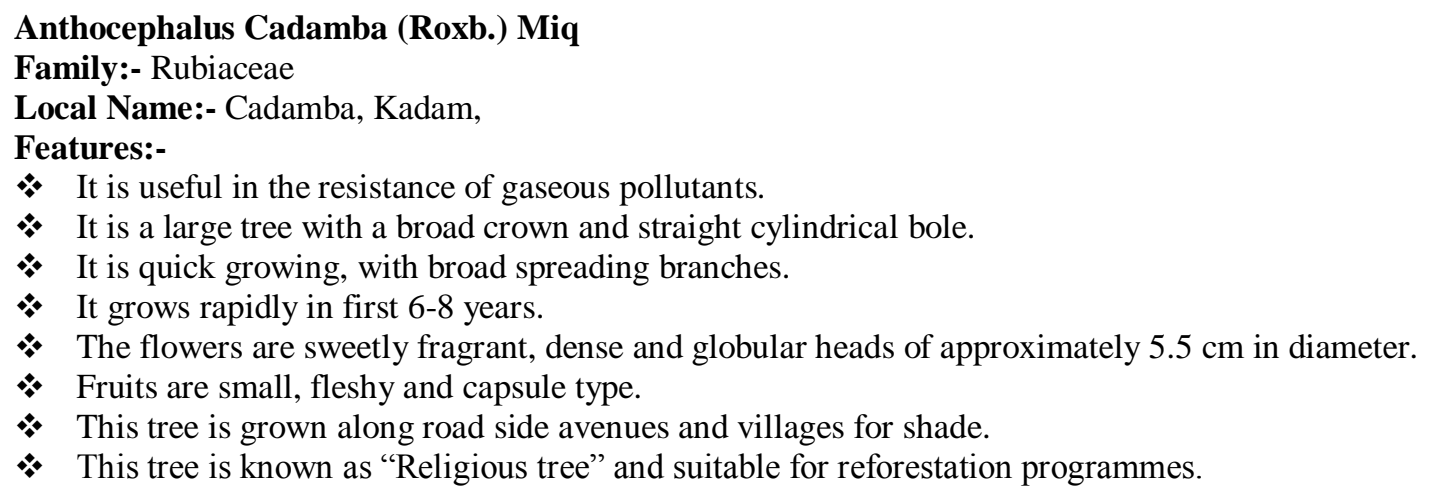

Azadirachta indica A. juss

Family:- Meliaceae

Local Name:-Neem

Features:-

* It has been referred as an "air purifier".

* It absorbs some of the pollutants as $\mathrm{SO}_{2}$.

* It act as an "air fresher" by releasing oxygen and odours principle.

* Leaves are resistant to gaseous pollutants.

* It is a fast growing tree that can reach a height of 15-20 meters rarely to 35-40 meters.

* It grows in the highly polluted area and drought condition.

* It is used in the medicines.

\section{Bougainvillea spectabilis Willd}

Family:- Nyctaginaceae

Local name:- Gatebel

Features:-

* It is an ornamental and evergreen plants.

* It can be kept as indoor house plants in temperate region. 
* It is a fast growing plant.

* Leaves are small and resistant to gaseous pollutions.

* It is a pest free plant but they may suffer from worms.

* It is planted along to the road side, avenue tree.

- It is used as a pollution indicator plant.

* The sap of Bougainvillea can cause serious skin rashes.

\section{Caesalpinia pulcherrima Linn}

Family:- Fabaceae

Local name:- Peacock flower

Features:-

* It is a striking ornamental plant.

* It is a shrub with beautiful flowers.

* It is more sensitive to cold.

* The flowers show high tolerance to chromium.

* This plant can grow in sunlight of part shade.

* It grows in public gardens.

\section{Delbergia sissoo Roxb}

Family:- Fabaceae

Local name:- Shishum

Features:-

* It is used as a wind break and shelter belt.

* Shishum has highly chlorophyll content to tolerance of the pollutants.

* An antioxidant ascorbic acid is present in the growing part of the plant and influences resistance to adverse air pollution.

* It is useful to monitor and indicate the lead concentration in air.

* It can grows in the stress, polluted and adrought area.

* It has a dense root system.

- It is helpful in the fertility of soil.

- It is planted in urban areas along roadsides and in gardens as an ornamental plants.

Ficus religiosa Linn

Family:- Moraceae

Local name:- Pipal

Features :

* Leaves contain tannin, Leucine tryptophan, methionine etc.

* It is a resistant to gaseous pollutants.

- It has a good canopy structure.

* It is a common tree of road side.

* It is a glabrous, large tree mostly covered with epiphytes.

* The leaves are big, upto $16 \mathrm{~cm}$. in length and limit a lot of oxygen in environment.

Nyctanthes arbortristis Linn.

Family name:- Oleaceae

Local name:- Harsingar

Features:-

* It grows on rocky ground in dry hill sides.

* It can grow in full sunlight or partial shade.

* It is a large shrub growing upto 10 meter tall.

* The leaves are rough and hairy which help in retaining the dust and particulate pollution.

- It has a good canopy. 


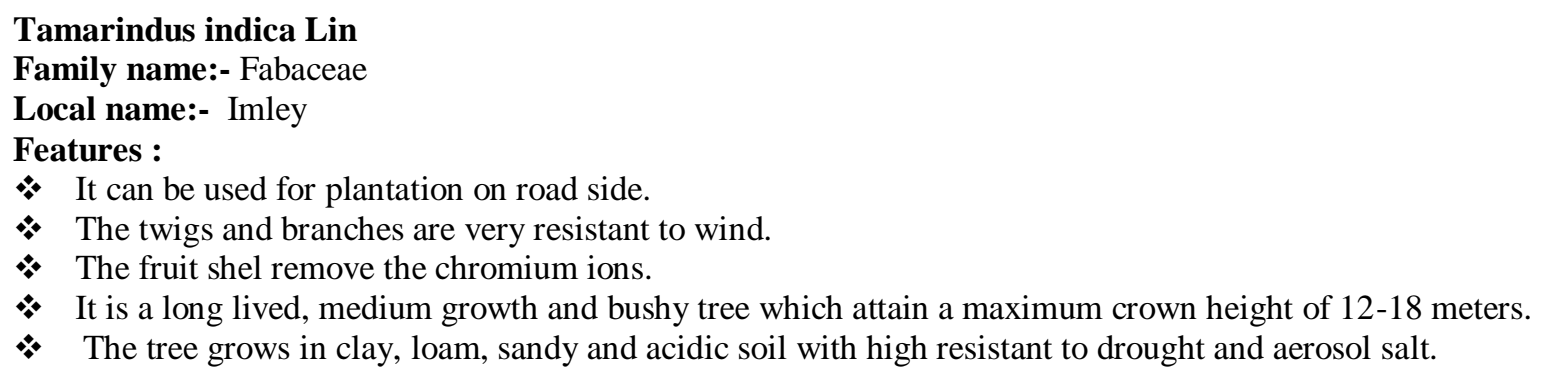

\section{Thevetia neriifolia A.juss}

Family name:- Apocynaceae

Local name:- Pili kaner

Features :

* The tree grows in clay, loam, sandy and acidic soil with high resistant to drought and aerosol salt.

* It is an evergreen shrub or small tree up to 10-20 feet tall.

* Leaves are willow type and covered in waxy coating to resistant to gaseous pollutants.

* It contain a milky sap compound called "Thevetin" that is used in heart stimulant.

* It is planted along road sides avenue tree in the polluted areas.

* It is used as a pollution indicator.

\section{Discussion}

Vegetation naturally cleanses the atmosphere by absorbing gases and some particulate matter through leaves. Some plants have been classified according to their degree of sensitivity and tolerance towards various air pollutants. Sensitive plant species are used as bio-indicators. This study is useful for the better understanding and management of air quality as well as in selection of suitable plant species (with high APTI) for plantation in industrial area as well as roadside. Singh and Rao, (1983) have suggested a method of determining Air Pollution Tolerance Index (APTI) by synthesizing the values of four different biochemical parameters i.e. leaf extract, $\mathrm{pH}$, ascorbic acid, total chlorophyll and relative water contents.

The APTI was calculated by using the following formula (Singh and Rao, 1983). APTI=[A(T+P) $+\mathrm{R}] / 10$

Where, $\mathrm{A}=$ Ascorbic acid (mg/g dry wt.)

$\mathrm{T}=$ Total Chlorophyll (mg/g dry wt.)

$\mathrm{P}=\mathrm{pH}$ of leaf extract

$\mathrm{R}=$ Relative water content of leaf tissue $(\%)$.

Based on the APTI value the plants were conveniently grouped as follows (Kalyani and Singaracharya, 1995).

APTI Value response

Tolerant - 30 to 100

Intermediate - 29 to 17

Sensitive -16 to 1 and Very sensitive $-<1$

Albizia lebbeck Linn. (Willd.) - 32.5, Bougainvillea spectabilis Willd. - 30, Azadirachta indica A. juss-27.5 high tolerance, Ficus religiosa Linn -22.67 and Tamarindus indica Linn. - 14 moderate Tolerance (in descending order).

Studies shows dust removal capacities of various plants-(calculated by $\mathrm{gm} / \mathrm{m}^{2}$ ) Nyctanthes arbortristis Linn $2.48 \%$, Ficus religosa Linn - 6.62\%, Thevetia neriifolia Juss.-11.56\%, Anthocephalus cadamba (Roxb.) Miq.-17.71\%, Dalbergia sissoo Roxb.-16.02\% and Azadirachta indica A.Juss.-26.64\%.

\section{Conclusion}

India's rich biodiversity of both indigenous and exotic trees, offers a wide range of choice to restore our sick towns. The importance of trees in urban environment is now widely recognized that they too cleanse the particular air pollution and help to make cities and town more agreeable places to dwell upon. The study recommends various tree 
species for urban planting so that a wider usage of local as well as exotic tree species can be explored for controlling air born pollution in urban climate.

\section{References}

1. CPCB, 2006. Annual Report,4:80-99.

2. Gupta, R.B., Chaudhari, P.R. and WATE,S.R. 2008. Overview on attenuation of industrial air pollution by green belt. Jour. Ind. Poll. Contr.24(1):1-8.

3. Kapoor, B.B.S. and Kishore, K. 2013. Some Ethnomedicinal tree species of shekhawati region of Rajasthan used in folk and herbal medicines. uniq. Jour. Ayur. Herb. Med. 01(01):5-9.

4. Kumar, S. Arumugam, T. Anandakumar, C.R., Balakrishna,S. and Rajavel, D.S. 2013. Use of Plant species in controlling Environmental pollution-A Review. Bull. Env. Pharmacol. life sci. 2(2):52-63.

5. Rani,C., Chawala, S. Mangal,M.Mangal, AK, Kajala, S. and Dhawan,AK.2012. Nyctanthes arbortristis Linn. (Night Jasmine) : A Sacred ornamental plant with Immense medicinal potentials. Ind. Jour. Tradtl. Knowl. 11(3):427-435.

6. Sharma, P.D.2014. Ecology and Environment. Rastogi publication, Capital offeset press, New Delhi, India.255319.

7. Singh, V. 2013. Role of medicinal Plant in controlling environmental (Air) pollution. Internatl. Ayur. Med. Jour. 1(5). 